\title{
Evaluation Tool of Land Suitability for Medicinal Plants
}

\author{
SE Rahim ${ }^{1 *}$, AA Supli ${ }^{2)}$, D Damiri ${ }^{3)}$, Chairil Zaman $^{1)}$, Husin $^{1)}$ \\ ${ }^{1)}$ Bina Husada College of Health Sciences, Palembang, South Sumatra, Indonesia. \\ ${ }^{2)}$ Ph.D Multi-media student at Faculty of Computer Science, UUM Kedah, Malaysia. \\ ${ }^{3)}$ Department of Agrotechnology, Agriculture Faculty. University of Sriwijaya, South Sumatra, Indonesia. \\ *Corresponding author: sup_effendi@yahoo.co.id.
}

Article history

\begin{tabular}{llll}
\hline Received & Received from reviced & Accepted & Available online \\
06 January 2019 & 04 March 2019 & 28 March 2019 & 30 March 2019 \\
\hline
\end{tabular}

\begin{abstract}
Planting medicinal crops must be carried out on a land that is suitable based on the results of a land suitability evaluation. A framework to evaluate the land suitability is initiated by FAO. Smart phone nowadays becomes ubiquitous technology to solve problems in most settings, such as agriculture, medicine, and many others. This paper is to capitalize such advantage by converting the framework into a mobile app. This solution is hoped to help land users to be more effective and efficient in evaluating their land. An algorithm is employed in the form the Rule Based System (RBS) in a way to construct the framework into bunch of rules that connect each other, resulting the conclusion of suitability. The rules itself are working on annual rainfall, altitude, drainage, soils' type, $\mathrm{pH}$, flood risk, fertility of the soils, soil solum depth, etc. This study focuses on three medicinal crops only, which are candlenut, cardamom and onion to be evaluated. Data of agro climatic that were determining the suitability of the crops were developed into general and specific criteria for the plants. A usability model was studied from 40 respondents using the app. The usability of the app was in "very good" classification.
\end{abstract}

Keywords: suitability evaluation, FAO framework, medicinal plants.

Abstrak (Indonesian): Penanaman tanaman obat harus dilakukan di lahan yang sesuai berdasarkan hasil evaluasi kesesuaian lahan. Kerangka kerja untuk mengevaluasi kesesuaian lahan untuk banyak penggunaan lahan diprakarsai oleh Organisasi Pangan dan Pertanian (FAO). Telepon pintar saat ini menjadi teknologi di mana-mana untuk menyelesaikan masalah di sebagian besar pengaturan, seperti pertanian, kedokteran dan banyak lainnya. Makalah ini adalah untuk memanfaatkan keuntungan tersebut dengan mengubah kerangka kerja menjadi aplikasi seluler. Solusi ini diharapkan dapat membantu pengguna lahan atau perencana agar lebih efektif dan efisien dalam mengevaluasi tanah mereka. Algoritma digunakan dalam bentuk Rule Based System (RBS) dengan cara membangun kerangka kerja menjadi sekumpulan aturan yang menghubungkan satu sama lain, menghasilkan kesimpulan kesesuaian. Aturan itu sendiri bekerja pada curah hujan tahunan, ketinggian, drainase, jenis tanah, $\mathrm{pH}$, risiko banjir, kesuburan tanah, kedalaman solum tanah, dll. Penelitian ini berfokus pada tiga tanaman obat saja, yaitu kemiri, kapulaga dan bawang merah untuk dievaluasi. Data agro iklim yang menentukan kesesuaian tanaman dikembangkan menjadi kriteria umum dan spesifik untuk tanaman. Model kegunaan dipelajari dari 40 responden menggunakan aplikasi. Ditemukan bahwa kegunaan aplikasi berada dalam klasifikasi "sangat baik".

Kata kunci: evaluasi kesesuaian, kerangka kerja FAO, tanaman obat,

\section{Introduction}

The soil is the accumulation of the outer body occupying most of the earth's surface. The soil is capable of growing a plant including medicinal plants because it has properties as a result of climate influence and the living body acting on the parent material in certain relative circumstances over a certain period of time [1]. Land evaluation is part of the landuse planning process [2]. The core of evaluation is comparing the requirements demanded by the type of land use to be applied, with the properties or quality of the land to be used. In this way, the land potential or land suitability class for the type of land use will be known [3].
The development of medicinal plants such as candlenut, cardamomcardamom and onion is very important in efforts to increase the area of harvest and production. In order to increase the area of harvest and production it is desirable to know precisely where the appropriate area or potential for each type of medicinal plant, including where the appropriate area for the hazelnut, for cardamom or for onion. Research on the evaluation of land suitability for medicinal plants should continue.

A number of papers have been written concerning their land suitability classification. This classification was initiated by FAO in the late 1970s [4]. The evaluation itself fundamentally was measured by 
matching the land characteristics with the standard data of crop evaluation manually. However, calculating all those variables and matching them are more than meets the eye in which one will take much times and endeavors [5], [6], [7].

Manual approach in evaluating land suitability was carried out by many workers for example by [8] that study the suitability of coal mined area at PT. Bukit Asam Tanjung Enim, South Sumatra Indonesia. Based on his study, it was found that in general the post-mining land there was suitable for plantation crops. Another study in land evaluation was done manually by [9] that also evaluated the suitability for plantation crops on post-mining land. Other workers on the land suitability for medicinal plants are [10], [11] and [12]. Those three studies were the land suitability evaluation on candlenut, cardamom and onion respectively.

Contrast to the above mentioned studies, this paper reports the study that manages to develop a mobile application as to make the measurement more effective and efficient in evaluation the land suitability for herbal medicine crops. This study itself focuses on three herbal medicine crops, which are clove, cardamom and onion. This is as an enhancement of our previous studies of land suitability evaluation [7], [13] in form of mobile application that focused on plantation crops and food crops successively. Therefore, in order to create this application, which is elaborated from the FAO framework, it is important to know further the detail of the framework.

\section{Material and Methods}

The criteria for land suitability for medicinal crops are made in accordance with what is determined by scholars namely for candlenut, kapulaga and onion. Afterwards, a rule based system algorithm that was chosen in our previous work is a rule-based system (RBS) [6]. The algorithm is employed in the form the Rule Based System (RBS) in a way to construct the framework into bunch of rules that connect each other, resulting the conclusion of suitability. The rules itself are working on some variables, namely annual rainfall, altitude, drainage, soils' type, $\mathrm{pH}$, flood risk, fertility of the soils, soil solum depth, etc. This study focuses on three medicinal crops only, which are candlenut, cardamom and onion to be evaluated. Data of agro climatic that were determining the suitability of the crops were developed into general and specific criteria for the plants. A usability model was studied from 40 respondents using the app.

\section{Results and Discussion}

The criteria for land suitability for medicinal crops (candlenut, cardamom and onion) are as in Table 1, Table 2, and Table 3. One of the weaknesses of this table is that not all users can comprehend each term of it. Therefore, in order to meet the objective in this study (converting them into mobile app), the very first thing to do is to apply simplification towards each variable of land characteristic as well as its limiting factors. Principally, all terms were simplified into a form of simpler language with detail explanation so that the users can understand them better. The samples of such simplification can be seen in screen shot section.

Each land characteristic was changed into multiple-choice question to be answered by users. Nonetheless, there is one or two variables that were not inserted into the app, due to the difficulty to measure it, as a result default values were used for such variables that have the similarity result in soil types or regions. For instance, the annual rainfall is in general would be between 2000 and $3000 \mathrm{~mm}$. Additionally, the value is $>25^{\circ} \mathrm{C}$ for daily air temperature.

Table 1: Criteria for evaluation of land for candlenut (Aleurites moluccana WILLD.) [14].

\begin{tabular}{|c|c|c|c|c|}
\hline \multirow{2}{*}{ Land characteristics } & \multicolumn{4}{|c|}{ Limiting factors and land suitability classes } \\
\hline & S1 & $\mathrm{S} 2$ & S3 & $\mathrm{N}$ \\
\hline \multicolumn{5}{|l|}{ Climate condition (c) } \\
\hline Rainfall (mm) & $1500-2500$ & $1000-1499$ & $750-1000$ & $<750$ \\
\hline Temperature $\left({ }^{\circ} \mathrm{C}\right)$ & $25-28$ & $32-35$ & $18-15$ & $>35$ \\
\hline \multicolumn{5}{|l|}{ Topography } \\
\hline Topography of slope $(\%)$ & $0-4$ & $8-16$ & $16-30$ & $30-50$ \\
\hline Drainage & Fast & Slow & Very Slow & - \\
\hline Nutrient Availability(f) & $>50$ & $35-50$ & $<35$ & - \\
\hline $\mathrm{pH} \mathrm{H} \mathrm{H}_{2} \mathrm{O}$ & $6,4-6,8$ & $7,0-7,5$ & $5,0-6,3$ & $<5,0$ \\
\hline C-Organic & $>0.4$ & $0.3-0,4$ & $<0,3$ & - \\
\hline \multicolumn{5}{|l|}{ Alcalinities (n) } \\
\hline $\operatorname{ESP}(\%)$ & $0-8$ & $15-20$ & $20-25$ & - \\
\hline
\end{tabular}

Source:[10]. 
Table 2: Criteria for evaluation of land for condamom (Elletaria cordamomun Maton) based on [14].

\begin{tabular}{|c|c|c|c|c|}
\hline \multirow{2}{*}{ Land characteristics } & \multicolumn{4}{|c|}{ Limiting factors and land suitability classes } \\
\hline & S1 & S2 & S3 & N1 \\
\hline Altitude (m asl) & $600-1200$ & $\begin{array}{l}400-600 \text { or } \\
1200-1800\end{array}$ & $<400$ & $>1800$ \\
\hline $\begin{array}{l}\text { Climate condition }(\mathrm{c}) \\
\text { Rainfall }(\mathrm{mm}) \\
\text { Temperature }\left({ }^{\circ} \mathrm{C}\right)\end{array}$ & $\begin{array}{c}3000-5000 \\
20-23\end{array}$ & $\begin{array}{c}2000-3000 \\
23-33\end{array}$ & $\begin{array}{c}<2000 \\
<20\end{array}$ & $\begin{array}{l}- \\
-\end{array}$ \\
\hline $\begin{array}{l}\text { Topography } \\
\text { Topography of slope (\%) } \\
\text { Erosion (W) } \\
\text { Drainage }\end{array}$ & $\begin{array}{c}<8 \\
\mathrm{~F}_{0} \\
\text { Fast }\end{array}$ & $\begin{array}{c}8-16 \\
- \\
\text { Moderate }\end{array}$ & $\begin{array}{c}16-30 \\
- \\
\text { Poor }\end{array}$ & $\begin{array}{l}>30 \\
- \\
-\end{array}$ \\
\hline $\begin{array}{l}\text { Physical of the Soil(s) } \\
\text { Texture } \\
\text { Effective Depth }(\mathrm{cm})\end{array}$ & $\begin{array}{l}\text { C,SiC,SiCl, } \\
\text { Cl,SiL,SC } \\
>150\end{array}$ & $\begin{array}{c}\text { C,fs } \\
100-50\end{array}$ & $\begin{array}{l}\text { S,cs } \\
50-25\end{array}$ & - \\
\hline $\begin{array}{l}\text { Nutrient Availability(f) } \\
\mathrm{CEC}(\mathrm{cmol} /(+) \mathrm{kg} \text { soil }) \\
\mathrm{BS} \\
\mathrm{pH} \mathrm{H}_{2} \mathrm{O} \\
\text { C-Organic }\end{array}$ & $\begin{array}{c}>16 \\
>35 \\
6,0-7,5 \\
>1,5\end{array}$ & $\begin{array}{l}\leq 16 \\
<20 \\
5,5-6.0 \\
<0,8\end{array}$ & $\begin{array}{l}- \\
- \\
<5,5 \\
-\end{array}$ & $\begin{array}{l}- \\
- \\
<4,5 \\
-\end{array}$ \\
\hline $\begin{array}{l}\text { Alcalinities (n) } \\
\text { ESP }(\%)\end{array}$ & $0-15$ & - & - & - \\
\hline
\end{tabular}

Source: [10]

Table 3: Criteria for land evaluation for Onion (Annona muricata L.) based on [14]

\begin{tabular}{|c|c|c|c|c|}
\hline \multirow{2}{*}{ Land characteristics } & \multicolumn{4}{|c|}{ Limiting factors and land suitability classes } \\
\hline & S1 & S2 & S3 & $\mathrm{N}$ \\
\hline \multicolumn{5}{|l|}{ Climate condition (c) } \\
\hline Rainfall (mm) & $350-600$ & $600-800$ & $800-1600$ & $>1600$ \\
\hline Temperature $\left({ }^{\circ} \mathrm{C}\right)$ & $20-25$ & $25-29$ & $30-35$ & - \\
\hline \multicolumn{5}{|l|}{ Topography } \\
\hline Topography of slope (\%) & $0-4$ & 8-16 & $16-30$ & $30-50$ \\
\hline Drainage & Fast & Moderate & - & - \\
\hline Physical of the Soil(s) & $\mathrm{C}, \mathrm{SiC}, \mathrm{SiCl}$, & & & \\
\hline Texture & Cl.SiL SC & C.fs & S.cs & _ \\
\hline Effective Depth (cm) & $>150$ & $100-50$ & $50-25$ & - \\
\hline Nutrient Availability(f) & $>2,8$ & $<1,6$ & - & - \\
\hline $\mathrm{CEC}(\mathrm{cmol} /(\mathrm{kg}$ soil $)$ & $>35$ & $<20$ & - & - \\
\hline BS $(\%)$ & $6,0-7,8$ & $5,8-6,0$ & $<5,8$ & - \\
\hline $\mathrm{pH} \mathrm{H}_{2} \mathrm{O}$ & $>1,2$ & $2-3$ & $3-5$ & $>5$ \\
\hline \multicolumn{5}{|l|}{ Alcalinities (n) } \\
\hline $\operatorname{ESP}(\%)$ & $<20$ & $20-35$ & $35-50$ & $>50$ \\
\hline
\end{tabular}

Legend: C (clay), SiC(silty clay), SiCL (silty clay loam), Si (silt), SiL (silty loam), CL (clay loam), LS ( loamy sand), $\mathrm{LcS}$ ( loamy coarse sand, $\mathrm{Cm}$ (massive clay), SiCm ( silty massive clay), BS (base saturation), CEC (cation exchange capacity).

Source: [12].

\subsection{Suitability Evaluation of Medicinal Crops} Application and Screenshot

Our previous work proved that land suitability assessment using mobile application is useful and easy to use for users, compared to using manual approach that needs more efforts to collect data extracting from soil laboratory analysis and geo-physics data and Indonesia climate information. The point is that there are many things to be settled down when facing agricultural crops' requirement [6].
In this work, the authors put highlight on creating app that deals with general and specific criteria for medicinal crops namely candlenut, cardamom and onion. This study is highly motivated at the same time to encourage the Indonesian government, especially ministry of agriculture, students and land use planners to use this application, due to is simplicity, effectiveness and efficiency in assessing the land suitability. This app is very needed by land managers in many areas of Indonesia. 
The application is very straight to the point and easy to execute, providing the user (s) the criteria of the land they desire to be evaluated. The conclusion for land suitability classes is given promptly. The screenshot of the app can be seen, as follows:

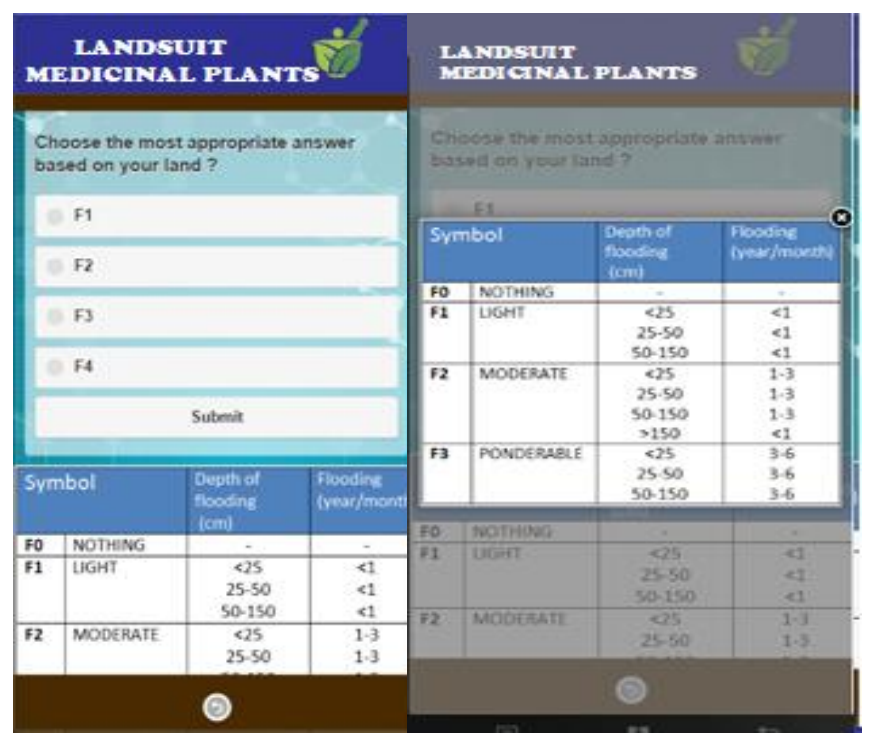

Figure. 1. Deep Flooding Factor with its explanation table

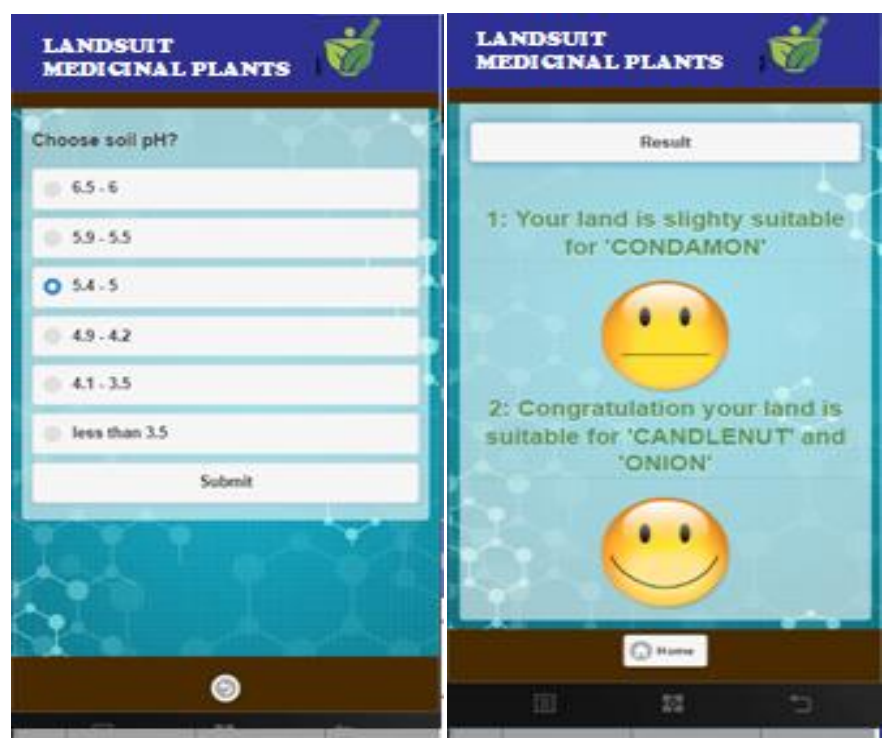

Figure. 2. Soil $\mathrm{pH}$ and result of the land suitability evaluation

\subsection{Usability of The Application}

To measure several criteria of the made application was conducted by testing the usability of the application. A mobile usability model by [15] is selected. This model is used for it is specially for mobile application usability. Three main usability characteristics in this model are: Effectiveness, Efficiency and Satisfaction (see Table 4). Each of these characteristics is divided into several subcharacteristic and guidelines. A comprehensive experiment and survey to assess all characteristics were carried out. The users were also prompted to finish some tasks and from there we observe and assess the accuracy, time taken, error-free, etc.

Table 4: Usability Characteristic

\begin{tabular}{|c|c|c|}
\hline $\begin{array}{l}\text { Characteristic } \\
\text { of the quality }\end{array}$ & $\begin{array}{c}\text { Sub- } \\
\text { Characteristic } \\
\text { (Goal) }\end{array}$ & Guidelines \\
\hline \multirow[t]{2}{*}{ Effectiveness } & Simplicity & $\begin{array}{l}\text {-Ease to learn } \\
\text {-Ease to input the } \\
\text { data } \\
\text {-Ease to use output } \\
\text {-Ease to install }\end{array}$ \\
\hline & Accuracy & $\begin{array}{l}\text {-Accurate } \\
\text {-Should be error- } \\
\text { free } \\
\text {-Successful }\end{array}$ \\
\hline \multirow[b]{2}{*}{ Efficiency } & Time taken & $\begin{array}{l}\text {-To respond } \\
\text {-To complete a task }\end{array}$ \\
\hline & Features & $\begin{array}{l}\text {-Support/help } \\
\text {-Touch screen } \\
\text { facilities } \\
\text {-Voice guidance } \\
\text {-System resources } \\
\text { info. } \\
\text {-Automatic update }\end{array}$ \\
\hline \multirow[t]{2}{*}{ Satisfaction } & Safety & $\begin{array}{l}\text {-While using the } \\
\text { application } \\
\text {-While driving }\end{array}$ \\
\hline & Attractiveness & -User interface \\
\hline
\end{tabular}

Source: [7].

A convenience sampling was chosen before studying the usability of the application. Relevant respondents from any member of agricultural sectors and medicinal plants, that are willingly to join, are selected [16], [6], [8]. Additionally, in order to determine the sample size, rules of thumb can be applied, as follows: (1) The number of respondents between 30 and 500 are appropriate for most studies. (2) For simple experimental research but with tight experimental controls, it is also possible to collect respondents from 10 to 20 in size [17].

This study succeeded to collect 40 people for the experiment. The demography of those respondents as seen in table 5. Subsequently, the respondents were explained though power point presentation about how to use the prototype and how to fill the questionnaire lastly, they were asked to do some tasks and fill the usability questionnaire at their own pace. In the middle of session, they were given the opportunity to also question anything regarding the prototype as well as the usability testing. The questionnaire prepared was using 5 point Likert scale (see figure 7). 
Table 5: Demography of Respondent

\begin{tabular}{cccccc}
\hline & \multicolumn{2}{c}{$\begin{array}{c}\text { Frequen } \\
\text { cy }\end{array}$} & Percent & $\begin{array}{c}\text { Valid } \\
\text { Percent }\end{array}$ & $\begin{array}{c}\text { Cumula } \\
\text { tive } \\
\text { Percent }\end{array}$ \\
\hline \multirow{4}{*}{ Valid } & Lecturer & 10 & 24.3 & 24.3 & 24.3 \\
Civ. & 9 & 22.9 & 22.9 & 47.1 \\
& Servants & & & & \\
& Students & 9 & 22.9 & 22.9 & 70.0 \\
& Farmer & 12 & 30.0 & 30.0 & 100.0 \\
Total & 40 & 100.0 & 100.0 & \\
\hline
\end{tabular}

As mentioned earlier, specifically for measuring accuracy, respondents were asked to do some tasks. They the reviewers of us were then measuring and recording some metrics based on guidelines of usability model, which are (1) time-taken (2) number of errors (3) number of successful task at the first attempt (4) and number of successful tasks in a given time. In other parts (usability characteristic), they were then directed to check the answer for each question using 5 points of likert-scale.

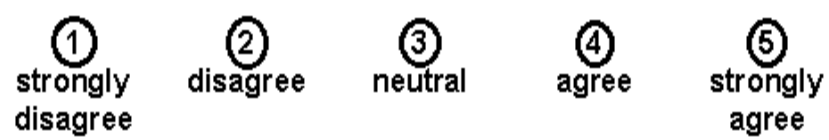

Figure 3. Likert Scale 5 Point

The data analysis was then carried out using SPSS software with descriptive analysis frequency feature. This includes the results of mean, minimum and maximum value for each usability characteristic. (see Table 6 and Table 7)

Table 6: Sub-characteristic Statistic Results

\begin{tabular}{|c|c|c|c|c|c|c|c|}
\hline & & Simplicity & Accuracy & Time_Taken & Features & Safety & Attractiveness \\
\hline \multirow[t]{2}{*}{$\mathrm{N}$} & Valid & 40 & 40 & 40 & 40 & 40 & 40 \\
\hline & Missing & 0 & 0 & 0 & 0 & 0 & 0 \\
\hline \multicolumn{2}{|c|}{ Mean } & 4.1400 & 3.9714 & 4.2905 & 4.3200 & 4.1000 & 4.3143 \\
\hline \multicolumn{2}{|c|}{ Minimum } & 2.40 & 2.00 & 3.00 & 3.00 & 2.67 & 3.00 \\
\hline \multicolumn{2}{|c|}{ Maximum } & 5.00 & 5.00 & 5.00 & 5.00 & 5.00 & 5.00 \\
\hline
\end{tabular}

Table 7: Quality Characteristic Statistic Results

\begin{tabular}{|c|c|c|c|c|}
\hline & & $\begin{array}{c}\text { Effectiven } \\
\text { ess }\end{array}$ & Efficiency & $\begin{array}{c}\text { Satisfactio } \\
n\end{array}$ \\
\hline \multirow[t]{2}{*}{$\mathrm{N}$} & Valid & 40 & 40 & 40 \\
\hline & Missing & 0 & 0 & 0 \\
\hline \multicolumn{2}{|c|}{ Mean } & 4.0557 & 4.3052 & 4.2071 \\
\hline \multicolumn{2}{|c|}{ Minimum } & 2.20 & 3.00 & 3.00 \\
\hline \multicolumn{2}{|c|}{ Maximum } & 5.00 & 5.00 & 5.00 \\
\hline
\end{tabular}

Interpreting the results used the five-point scale (see table 8). It was found that all sub-characteristics achieved "very good scale" based on table 8 interpretation, which are ranging from 3.42 to 4.42 point. As a result, overall results from all three major characteristics: Effectiveness, Efficiency and Satisfaction are "very good scale", which are respectively scoring the mean value: $4.05,4.30$, and 4.20. This can be concluded that all respondents were having a very good perspective in terms of its usability of the system.

Table 8: The Five-Point Likert Scale

\begin{tabular}{cc}
\hline Range & Classification \\
\hline $1.00-1.80$ & Poor \\
$1.81-2.61$ & Fair \\
$2.62-3.41$ & Good \\
$3.42-4.42$ & Very Good \\
$4.43-5.23$ & Excellent \\
\hline
\end{tabular}

\section{Conclusion}

Evaluation tool for land suitability classification for three medicinal crops namely candlenut, cardamom and onion has been derived. General and specific criteria affecting the land suitability for the crops were developed from the data of agro climatic in the earlier studies. Based on the criteria, a mobile program in the android was designed and implemented. The usability of the app studied among land users and showed a "very good" classification in which the all average means of all characteristic were in the between range 3.97 and 4.32. This program will be designed to cross platform technology in which it will enable app to exist in Android, iOS, windows, and many other mobile operating system. The program is urgently needed by the land managers, farmers, companies especially those who deal with medicinal plants.

\section{Acknowledgement}

The authors would like to express thanks to the authors' head of institutions who have given a wider opportunity and support during the program development and the writing of this paper.

\section{References}

[1] Susanto. "Young Children and Agriculture, editor Winangun, Wartoyo, Building the Character of Organic Farmers Success in Globalization Era", 2005, Publisher Kanisius, Yogyakarta. 
[2] Rahim, SE. "Control of soil erosion to preserve the environment, 2013, Publisher PT. Bumi Aksara. Jakarta. 146p.

[3] Hardjowigeno and Widiatmaka. "Land suitability evaluation and land use planning", 2007, Gadjah Mada University Press. Yogyakarta.

[4] FAO. "A Framework for Land Evaluation", 1976, Soil Resources Development and Conservation Service Land and Water Development Division Food and Agriculture Organization of the United Nations Published by arrangement with the Food and Agriculture Organization of the United Nations.

[5] Djaenuddin, Df. "Evaluation of land for alternative crop development direction in support of agribusiness activities', 1995, Research Center for Soil and Agro-climate. Bogor.

[6] Rahim, SE., A.A. Supli, N. Shiratuddin, Nurhayati and Z.S. Mukti. "A confirmity tool for land evaluation in android mobile application", 2015, Paper presented in IJCIMBI 2015, Banda Aceh Indonesia, 27-28 April 2015.

[7] Rahim, SE, AA. Supli and N. Damiri. "Developing a land suitability evaluation in mobile android application for rubber, cocoa and oil palm”, 2016, J. ISSAAS Vol. 22, No. 2: 80-90.

[8] Hermawan, B. 2011. Improving the quality of mined land through revegetation and suitability as crop lands. Proceedings of the National Seminar on Agriculture. Urgency and Control Strategy of Agricultural Land Transfer Function. Bengkulu July 7, 2011. ISBN 978-602-19247-0-9.

[9] Rahim, SE. "A land suitability classification for post-mining land of PT. Bukit Asam Tanjung Enim South Sumatra Indonesia", 2013, Paper presented in Seminar of Post-mining Land In Indonesia. University of Sriwijaya.

[10] Taiyeb, A. "Evaluation of land suitability for candlenut (Aleurites moluccana WILLD.) on the land system of Salo Saluwan in Palu City Central Sulawesi”, 2017, J. ForestSains 14 (2): 98-107.

[11] Rosman, R. "Study of the suitability of land and climate for cardamom. Agency for Spices and midicinal plants", 1987, Bul. Littro. Vol. 2 (1): 50-59.

[12] Rajagukguk, N, Z. Nasution and Razali. "The evaluation of land suitability for onion (Allium ascalonicum L.) in Muara Subdistrict of North Tapanuli District", 2014, Journal online Agroekologi Vol. 2 (3): 941-948.

[13] Rahim, S.E.; Supli,A.A.; Damiri, N. Soil Loss Prediction on Mobile Platform Using Universal Soil-Loss Equation (USLE) Model. MATEC Web of Conferences 97, 01066, 2017.

[14] Sys C, Van Ranst E, Debaveye I J, Beernaert F. "Land evaluation, Part III: Crop Requirements", 1993, General Administration for Development Cooperation, Agricultural publication-No. 7, Brussels-Belgium, 199.

[15] Hussain, A., Hashim, N. L., Nordin, N., and Tahir, H. M. 2013. A Metric-Based Evaluation Model For Applications On Mobile Phone. Journal of Information and Communication Technology (JICT). 12, 55-71.

[16] Bougie, R, \& Sekaran, U. "Research methods for business: A skill building approach", 2010. Wiley: London.

[17] Roscoe, JT. "Fundamental Statistics for the Behavioural Science", 1975, New York: Holt. 